\title{
MAINTAINING MODERATE ISLAM IN WEST JAVA: The Perspective of Five Islam Mass Organizations Concerning Intolerance Cases
}

\author{
Wawan Hernawan', Usep Dedi Rostandi², Didin Komarudin ${ }^{3}$ \\ 1,2,3 Universitas Islam Negeri (UIN) Sunan Gunung Djati, Bandung \\ J. A.H. Nasution No. 105 Cibiru Kota Bandung 40614 \\ E-mail: 1wawanhernawan@uinsgd.ac.id, 2derost@rocketmail.com,3dikom76@uinsgd.ac.id
}

\begin{abstract}
Maintaining Moderate Islam in West Java: The Perspective of Five Islam Mass Organization Concerning Intolerance Cases. This study discusses moderate Islam in West Java based on the perspectives of five mainstream Islam mass organizations (Ormas): Nahdatul Ulama (NU), Muhammadiyah, Islamic Community Unity (Persatuan Ummat Islam, PUI), Islamic Unity (Persatuan Islam, PERSIS), and Jami'atul Washliyah, concerning intolerance cases in the province in recent years. These five Islam mass organizations have roles in West Java and their perspectives are also necessarily needed to consider especially in the middle of radical-liberal, secularfundamental streams. The study employs the Quintan Wiktorowicz socio-religious research methodology through documentation, observation, and interview techniques. The results show that the cases of intolerance in West Java have not yet resolved. There are internal, cross- and inter-religious factors both to promote and to inhibit this issue. Therefore, maintaining and giving space to the moderate Islam mass organization is suggested, as a frame in forming the behavior and religious pattern in the community.
\end{abstract}

Keywords: moderate Islam; intolerance; religious harmony.

\begin{abstract}
Abstrak: Merawat Islam Moderat di Jawa Barat: Pandangan Lima Organisasi Masyarakat terhadap Kasus Intoleransi. Kajian ini membahas tentang Islam moderat di Jawa Barat. Kajian dilakukan untuk menggali pandangan lima organisasi massa (Ormas) Islam mainstream: Nahdatul Ulama (NU), Muhammadiyah, Persatuan Ummat Islam (PUI), Persatuan Islam (PERSIS), dan Jami’atul Washliyah tentang kasus intoleransi yang terjadi di provinsi ini pada beberapa tahun terakhir. Kelima organisasi ini memiliki pengaruh yang kuat di Jawa Barat dan pandangan mereka sangat dibutuhkan terutama di tengah-tengah aliran radikal, sekuler-fundamental. Kajian ini menggunakan kerangka metode penelitian sosial keagamaan Quintan Wiktorowicz melalui teknik dokumentasi, observasi, dan wawancara. Hasil kajian menunjukan bahwa kasus intoleransi di Jawa Barat belum menandakan akan berakhir karena terdapat faktor internal antar-umat beragama dan antara umat beragama dengan pemerintah sebagai pendukung dan penghambat upaya meminimalkan kasus tersebut. Untuk itu, merawat dan memberi ruang keumatan kepada organisasi massa (ormas) Islam moderat sangat signifikan dilakukan guna dijadikan kerangka acuan dalam pola laku dan pola agama masyarakat.
\end{abstract}

Kata kunci: moderasi Islam; intoleransi; kerukunan beragama.

\section{Introduction}

At the end of 2015, people were surprised by a survey results of the Setara Institute and the Wahid Institute which claimed that West Java as the most intolerant province in Indonesia. ${ }^{\text {TTe }}$ six cities in West Java which were in top

1 Setara Institute, Report Summary Tolerant City Index 2015, (Jakarta: Setara Institute, 2015), p. 4. See also, The Wahid Institute, Laporan Tahunan Kemerdekaan Beragama/ Berkeyakinan (KBB) di Indonesia: "Utang” Warisan Tak Kunjung Terlunasi, (Jakarta: The Wahid Institute, 2015), p.33. ten are Bogor (5,21\%), Bekasi (4,68\%), Depok (4,26\%), Bandung (4,16\%), Sukabumi (4,05\%), and Tasikmalaya (4\%). ${ }^{2}$ In 2016, the similar surveys were also conducted by the National Human Rights Commission (HAM) ${ }^{3}$, The Center and the Study of Religion and Democracy (PUSAD) ${ }^{4}$ of

${ }^{2}$ Setara Institute, Report Summary Tolerant ..., p. 4.

3 Komnas HAM, Laporan Tahunan Kebebasan Beragama dan Berkeyakinan 2016, (Jakarta: Komnas HAM, 2016), p. 21.

4 Ayu Mellisa et al., Mengukur Kebebasan Beragama di Jawa Barat 2014: Catatan dari Indeks Demokrasi Indonesia, (Jakarta: PUSAD Paramadina, 2016), p. 9. 
Paramadina. The result was still worrying, West Java is still considered as the most intolerant province in Indonesia. ${ }^{5}$ Allegedly, the findings marked the emergence of an awareness of all elements of the nation and the government. Therefore, through the Ministry of Religion ${ }^{6}$ the concept of "Moderate Islam" is formulated.

Before this survey above was conducted, several mainstream Islam mass organizations, such as Nahdatul Ulama (NU), Muhammadiyah, Persatuan Ummat Islam (Islamic Community Unity, PUI), Persatuan Islam (Islamic Unity, PERSIS), and Jam'iyatul Washliyah have divulged the wasathiyah (moderate) Islamic movement ${ }^{7}$ which is characterized by modern behavior and cultural pattern. It is similar to the local wisdom of the West Javanese people who put forward the principle of siger tengah (the middle side), nonmilitant, non-extreme, and non-revolutionary. ${ }^{8} \mathrm{It}$ also requires a society that treats its citizens with dignity and respect 9 let alone room for any political intimidation or norm. Moderate individuals look forward to ethical life because they realize that they really want to do so. ${ }^{10}$ Moderate community members will compete in ta'awanu 'ala al-birri wa at-taqwâ (cooperate in righteousness and piety)" and wa lâ ta'awanu 'ala al-ismi wa al-'udwân (don't cooperate in sin and aggression). ${ }^{12}$ They believe that the messages of

\footnotetext{
${ }^{5}$ Komnas HAM..., p. 21. See also H. Riyadi, “ Koeksistensi Damai dalam Masyarakat Muslim Modernis", Wawasan: Jurnal Ilmiah Agama dan Sosial Budaya, Vol. 1, No. 1, 2016, pp. 18-33.

${ }^{6}$ Komnas HAM..., p. 21.

7 See, PB NU, Anggaran Dasar Nahdlatul Ulama, (Jakarta: PB NU, 2010), pp. 11-12; PP Muhammadiyah, Anggaran Dasar dan Anggaran Rumah Tangga Muhammadiyah, (Jakarta: PP Muhammadiyah, 2005), p. 2; PP Persis, Qanun Asasi/Qanun Dakhili Persis, (Bandung: PP Persis, 1991), 24-25; PB PUI, Badan Hukum, Anggaran Dasar/ART “PUI”, (Majalengka: PB PUI Majlis Penyiaran, Penerangan dan Dakwah, 1989), pp. 2-3; PB AlWashliyah, Anggaran Dasar Al-Jam'iyatul Washliyah, (Medan: PB Al-Washliyah, 2005), pp. 2-3.

${ }^{8}$ Tjetje H. Padmadinata, "Panggung Karakter Elite Sunda", in HU Pikiran Rakyat, April 5, 1997, p. 5.

9 John L. Esposito et al.,Moderat Atau Radikal, (Jakarta: Referensi, 2012), p.8.

10 PB NU, Nahdlatul Ulama Kembali Ke Khittah 1926, (Bandung: Risalah, 1984), p. 55. See also, John L. Esposito et al., p. 8.

${ }^{11}$ Nurhadi M. Musawir (ed.), Dinamika Pemikiran Islam dan Muhammadiyah: Almanak Muhammadiyah Tahun 1997 M./14171418, (Yogyakarta: Pustaka Pelajar, 1997), p. 6.

12 Kuntowijoyo, Paradigma Islam Interpretasi Untuk Aksi, (Bandung: Mizan, 1991), p. 229. See also, Ridwan, Paradigma
}

moderate Islam will bear the social transformation towards a society that upholds virtue. Islam does not teach its adherents to be moderate in the sense of accepting or carrying out some of the values of Islam, but acting in moderation in words, deeds, and practicing religion. ${ }^{13}$

In West Java, the harmonious relationship among Muslims and followers of other religions in recent years tends to decline. According to several surveys, radical Muslim groups breed the seeds of intolerance which lead to hatred among Muslims and non-Muslims by in the name of Islam. ${ }^{14}$ As a result, it always occupies the position as the most intolerant province in Indonesia. In situations and conditions that are less favorable, it is deemed necessary for individuals, groups or academics to explore, study, and find traces of moderate Islam as a public development.

Since five Islam mass organization shave roles in West Java, their perspectives are also necessary to consider especially in the middle of radical-liberal, secular-fundamental streams. The idea of moderating Islam can be traced through the perspectives of the leaders of the mass organizations, as well as the charity of the efforts that they believe in..$^{15}$ These perspectives and activities are expected to be able to bridge the lack of harmony of internal, cross- and interreligious groups with the government, ${ }^{16}$ so that intolerant practices can be minimized. Thus, understanding of moderate Islam becomes an alternative 'renewed' understanding of religion amid the onslaught of intolerance and radicalism.

\section{Method}

This research was conducted in Bandung Raya. This study employs social movement theory from Quintan Wiktorowicz with a multidisciplinary

Politik NU: Relasi Sunni-NU Dalam Pemikran Politik, (Purwokerto: STAIN Purwokerto Press, 2004), p. 203.

13 John L. Esposito et al. Moderat Atau Radikal, (Jakarta: Referensi, 2012), p. 8.

14 Sukawarsini Djelantik et al., Terorisme dan Kekerasan Berlatar Belakang Agama Di Jawa Barat, (Bandung: LP2M Universitas Parahyangan, 2013), p. 14.

${ }^{15}$ Ahsanul Khalikin dan Fathuri, Toleransi Beragama di Daerah Rawan Konflik, (Jakarta: Puslitbang Kehidupan Keagamaan Badan Litbang dan Diklat Kemenag RI, 2016), pp. 55-56.

${ }^{16}$ Ahsanul Khalikin dan Fathuri, Toleransi Beragama ..., pp. 56-57. 
approach through techniques of documentation, observation, and interviews. ${ }^{17}$ Searches were conducted on five mass Islamic organizations, online media, and libraries. Examinations through online media and libraries are important in order to trace the old sources in the form of survey reports, official organization documents, books, newspapers, magazines, and photographs related to the scholars and activities that were not obtained by the Regional Leaders of Islam mass organizations in West Java.

At the observation stage, it is considered successful if it is able to connect between information received and the situation and conditions that surround the object of study. ${ }^{8} \mathrm{Hence}$, it can be obtained through the relationship between information with the situation and conditions that surround it. Interviews were also conducted to get information about responses, offers, and efforts of moderate Islam in West Java. This stage was used to find emic information. In the next stage, the information is criticized and interpreted, thus results an ethical view of the data. ${ }^{19}$

\section{Number of Violations of Freedom of Religion/Belief (KKB) in West Java}

When the government is perceived to have limited formal political space, activities of community empowerment through lowerclass Islamic activities can be used as tangible resources for mobilization. At the same time, movement entrepreneurs lend a certain amount of incentives - solidarity and purposive -20 in order to attract interest while binding on actors to join the organization of the socio-religious movements that they form. ${ }^{21}$ Consequently, opposition, violence, and demonstrations are emerged, which condemned the policy.

\footnotetext{
17 Wawan Hernawan, Seabad Persatuan Ummat Islam, (Bandung: PUI dan YMSI Cabang Jawa Barat, 2014), p. 28.

18 Dadang Kahmad, "Kajian tentang Pengambilan Keputusan untuk menjadi Pengikut Tarekat Qadiriyah Naqsabandiyah; Studi Kasus di Kecamatan Ujungberung Bandung", Thesis, Universitas Padjajaran Bandung, 1993, p. 73.

${ }^{19}$ Dadang Kahmad, "Kajian tentang Pengambilan ..., p. 73.

${ }^{20}$ Dadang Kahmad, "Kajian tentang Pengambilan ..., p. 73

${ }^{21}$ Dadang Kahmad, “Kajian tentang Pengambilan ..., p. 73.
}

In 2015, Setara Institute ${ }^{22}$ recorded 196 incidents of violations of Freedom of Religion / Belief (KKB) with 236 forms of actions spread throughout Indonesia. Compared to 2014, this figure shows a significant increase. The highest number of violations occurred in West Java. This province has become a place of the proliferation of violations, namely with 44 events. Aceh Province followed West Java with 34 violations, East Java ranked the third with 22 violations, DKI Jakarta with 20 violations, and D.I Yogyakarta with 10 violations. ${ }^{23}$

The number of complaints of violations of rights to the Freedom of Religion and Belief that come into the National Human Rights Commission (Komnas HAM) in 2016 was 97 cases with an average of 8 complaints each month. The number had increased from all complaints in 2015, which amounted to 87 cases with an average of 7 proposals for complaints each month. ${ }^{24}$ The amount, according to Komnas HAM, has not yet reflected the actual number of violations of rights to KBB, because the cases that were filed were only a small part of the number of cases that occurred. The increase in the number of complaints can also be used as a parameter of growing public awareness in reporting cases of violations of rights to the KBB experienced by the National Human Rights Commission. ${ }^{25}$

Looking at the data from the National Human Rights Commission, the trend of intolerant behavior in 2016 was dominated by issues of rejection and destruction of places of worship. During this year, the 44 complaints were identified. The actions that could be categorized as intolerant, the restriction and prohibition of worship and the like, were 19 complaints. Although its position was the same as in 2015 , the issue of restrictions and prohibitions on worship and religious activities in 2016 had decreased in

\footnotetext{
${ }^{22}$ See, Halili and Bonar Tigor Naipospos, Laporan Kondisi Kebebasan Beragama/Berkeyakinan di Indonesia 2015: Politik Harapan Minim Pembuktian, (Jakarta: Pustaka Masyarakat Setara, 2016), p. 32.

23 Halili and Bonar Tigor Naipospos, Laporan Kondisi Kebebasan..., p. 34.

${ }^{24}$ Komnas HAM, Laporan Tahunan Kebebasan Beragama dan Berkeyakinan 2016, (Jakarta: Komnas HAM, 2017), p. 14.

${ }^{25}$ Komnas HAM, Laporan Tahunan Kebebasan ... , p. 14
} 
intensity. While for the ban on religious activities were 24 complaints. ${ }^{26}$ Issues that were quite get an attention in 2016 were threats or intimidation of religious groups with 12 complaints. This shows that the violation of the right to freedom of religion and belief through threats or intimidation on behalf of religion to religious groups has increased from the previous year. ${ }^{27}$

According to Bonar Tigor Naipospos and Halili, out of 201 intolerant actions, there were 75 violations in which the suspect were issuing the state administrators. Of the total state actions, 71 of them are in the form of active actions (by commission), three policy actions (by rule), while there were recorded one other action in the form of omission (by omission). Some of the violations by the state commission, according to Bonar and Halili, were statements of public officials who were provocative and encouraged condoning. For violations involving the state as an perpetrator, the legal guideline for accountability is Human Rights law. ${ }^{28}$ Still, according to Bonar and Halili, state actors who had committed the most violations were especially from the Regional Government (Pemda), with 25 violations. Other states who often act by a commission with high numbers were the Police. This institution in 2017 took action by a commission of 17 violations. Meanwhile, three other institutions in the category of state actors who frequently committed violations by the commission were educational institutions with 7 violations, the District Court with 5 violations, and the Civil Service Police Unit with 5 violations. ${ }^{29}$

From the number of violations of rights to freedom of religion and belief, there were also 126 cases of violations committed by individual citizens and individuals who were members of community organizations ( 28 violations). All actions by citizen groups fall into the category of criminal acts, so they were not difficult for the state to proceed them in accordance with applicable laws in Indonesia, meanwhile non-state actors who also violated the rights to Freedom

\footnotetext{
${ }^{26}$ Komnas HAM, Laporan Tahunan Kebebasan ..., pp. 17-18.

${ }_{27}$ Komnas HAM, Laporan Tahunan Kebebasan ..., p. 17.

${ }^{28}$ Komnas HAM, Laporan Tahunan Kebebasan ..., p. 17.

${ }^{29}$ Komnas HAM, Laporan Tahunan Kebebasan ..., p. 17.
}

of Religion and Belief respectively were: Islam mass organizations Alliance with 15 violations, Indonesian Council of Ulama (MUI) violations with 10 violations, Islamic Defenders Front (FPI) and individuals respectively with 6 violations and 5 violation. ${ }^{30}$

On June 3oth 2018 - Bonar Tigor Naipospos and Halili also exposed reports of violations of rights to Freedom of Religion and Belief. In his report, 109 incidents of violations were recorded with 136 actions. He said that the violations were spread in 20 provinces. Surprisingly in the report, after a long time, West Java has always been named the most intolerant province in Indonesia, in this report; the title was carried out by the province of DKI Jakarta, with 23 events. Still according to Bonar Tigor Naipospos and Halili, until the end of the first semester of 2018, there were only 19 violations in West Java. This condition placed it in the second place, because in other provinces, namely East Java, there were only 15 cases of violations, while the fourth position is occupied by Yogyakarta. In this area despite claiming to be a city of tolerance, there were still 9 violations. Furthermore, Nusa Tenggara Barat (NTB) ranked one of the top five provinces with the highest number of violations. In this province up to mid-2018, there have been 7 violations of KBB. ${ }^{31}$

Of the 136 reports of violations of rights to Freedom of Religion and Belief, there were 40 violations involving state officials as the actors. The highest number of violations committed by state actors is the criminalization of 7 violations, discrimination by commission (active action) and by rule (policy actions) of 5 violations. Furthermore, acts of intolerance were 4 violations; prohibitions of the veil were 3 violations; banning valentine celebrations was 3 violations, and the acts of expelling were 2 violations. Of the 136

\footnotetext{
${ }^{30}$ Komnas HAM, Laporan Tahunan Kebebasan ..., p. 17.

${ }^{31}$ Bonar Tigor Naipospos and Halili, Ringkasan Eksekutif: Laporan Tengah Tahun Kondisi Kebebasan Beragamal Berkeyakinan dan MiKomnasnoritas Keagamaan di Indonesia 2018, (Jakarta: Pustaka Masyarakat Setara, 2018), pp. 1-2. See also, Furqon Ulya Himawan. "Kalahkan Jawa Barat DKI Jakarta Jawara Intoleran”, in http://mediaindonesia.com/-read/ detail/179687-kalahkan-jawa-barat-dki-jakarta-jawara-intoleran. accessed August 26, 2018, accessed, August 26, 2018
} 
reports of violations of rights to $\mathrm{KBB}$, there were also 16 other violations, each of which were carried out by state actors, ranging from requiring hijab to desolating religious activities. ${ }^{32}$

\section{Responses and Offers of Islamic Mass Organization Leaders Concerning Cases of Intolerance}

According to Din Syamsuddin, moderate Islam mass organizations emerged and flourished in the local and national scope. They became the mainstream of Indonesian Islam, starting from Jami'at Khair (1905), Islamic Trade Sarekat (SDI)/Sarekat Islam (1905/1911), Islamic Community Association (1911), Muhammadiyah (1912), AlIrsyad (1914), Mathla'ul Anwar (1916), Sumatra Thawalib (1920), Islamic Unity (1923), Nahdatul Ulama (1926), Jam'iyatul Washliyah (1930), Tarbiyah Islamiyah (1930), Al-Khairat (1930), Masyumi (1937), Dârud-Dakwah wal-Irsyad (1937), Nahdlatul Wathan (1953), Indonesian Islamic Da'wah Council (1967), Indonesian Mosque Council (1972), and a number of other national-scale organizations which reach more than $100 .{ }^{33}$

Furthermore, one of the characters of moderate Islam is al-hanifiyyah al-samhah, which is the spirit of seeking truth accompanied by an open-minded, generous and tolerant attitude. ${ }^{34} \mathrm{Al}$-hanifiyyah al-samhah also means strong determination while remain tolerant and open minded ${ }^{35}$. The concept, at least, contains two meanings, namely: first, Islam forbids enforcing in accepting the truth (belief, religion). Second, Islam advocates looking for similarities in diversity..$^{36}$ The diversity of religions embraced by humans is something that is natural and must be respected. ${ }^{37}$

${ }^{32}$ Bonar Tigor Naipospos and Halili, Ringkasan Eksekutif: Laporan Tengah Tahun ..., p. 2.

33 Din Syamsuddin et al., Wasatiyyat Islam Untuk Peradaban Dunia: Konsepsi Dan Implementasi, (Bogor: Usulan Indonesia untuk Konsultasi Tingkat Tinggi Ulama dan Cendekiawan Muslim Dunia Tentang Wasatiyyat Islam Bogor, 2018), p. 32.

34 Din Syamsuddin et al.,Wasatiyyat Islam Untuk ..., p. 14.

35 Din Syamsuddin, "Etika Kerukunan Internal Umat Islam dalam" dalam Desk KBB Komnas HAM Bekerjasama dengan HRWG https://hakberagama.or.id/penjelasan-prof-drdin-syamsuddin-tentang-etika-kerukunan-internal-umat-islam/. accessed October 28, 2018.

${ }^{36}$ See, Q.S. Ali 'Imran:64.

${ }^{37}$ Din Syamsuddin et al.,Wasatiyyat Islam Untuk ..., p. 14
According to Nahdatul Ulama, there are some factors that trigger the intolerant acts in society, for example, exclusive understanding, feeling the most right and being harmonious in the community caused by social inequality (economy, politics, education, and so on). Therefore, a forum for dialogue, tabayun (being mindful), and mutual respect for fellow believers should be carried out. Religion, society, and individual on this earth should be put forward, as well as the attitude of mutual awareness, that the cross of opinions and differences actually has become the "sunnatullâh" of the Almighty God as well as this country was built on the spirit of "Unity in Diversity". ${ }^{38}$

On another occasion, Ahmad Dasuki said, based on historical records, extreme Islam groups had a long-standing trace in West Java. The spotlight on West Java which is considered to be the place for the seeding of hard-line Islam groups has a strong historical precedent. One of the historical moments which in the context of the post-New Order (Soeharto reign) became important was the event of the DI / TII rebellion in the 1950s. By its supporters, the so-called Perda Syari'ah (Sharia Regulation) is seen as a precedent that shows that ideas and aspirations regarding the Islamic State have roots in the West Javanese society. Supporters of the ideas and practices of the Sharia Regional Regulation in Tasikmalaya, for example, often use these arguments in every political struggle. ${ }^{39}$ In addition to these long-term arguments, there were shortterm factors that influenced communalism in West Java after the fall of the New Order. If the threat to pluralism is presumed to come from an escalation of communalism-based politics especially religion and ethnicity, understanding how they work is an important question that must be answered immediately, because, in my opinion, "that's where the base of intolerant behavior," 40 said Dasuki.

For this reason, according Mujio Nurkholis

\footnotetext{
${ }^{38}$ Interview with Asep Saepudin Abdillah, PW NU West Java, May 14, 2018.

39 Interview with Ahmad Dasuki, PW NU West Java, May 14, 2018.

${ }^{40}$ Inrerview with Ahmad Dasuki, ...,. May 14, 2018.
} 
(one of NU figure) the jargon "Islam Nusantara" is launched. The concept of the Nusantara Islam is actually an identity politics about the direction and policy of NU propaganda. However, in its development there was a bias that has carried out by irresponsible sides. In the end, with the Nusantara, Islam identity politics, everything became Indonesianized, so now it seems like NU is somewhat "vis-à-vis" with another Islam. This is a challenge for us, ${ }^{41}$ Mujio continued.

In addition, Muhammadiyah strongly denounced all intolerant behavior. According to Zulkarnaen,42 "Do not let such brutal actions be repeated and all parties must not tolerate the slightest act that is prohibited by all religions and laws". According to him, the attack between the two religious leaders in West Java, for example, needed to be thoroughly investigated. In line with Zulkarnaen's opinion, Dikdik Dahlan Lukman added, every form of terror and violence by anyone and against anyone is an act of disrespect. Therefore, I, as a Muhammadiyah voters, insist that the authorities, immediately investigate the case objectively. ${ }^{43}$ To that end, added Dikdik Dahlan Lukman, Muhammadiyah invited all religious and national people to strengthen brotherhood, mutual respect, and love, and build sincere and harmonious social relations for the sake of the establishment of a peaceful, progressive and religious life and noble civilization in Indonesia. ${ }^{4}$

In line with that, lu Rusliana revealed, "religious and national people everywhere must remain calm and not easily provoked by number of intolerant cases in West Java". lu continued, all individuals were expected to remain wise and be proportional. ${ }^{45}$ Therefore, continued lu, all elements of the people must unite against all forms of terror. Do not let the religious community be corrupted by the reverence of worship and its harmony by irresponsible actions. Still, according to lu, religious life is not only

${ }^{41}$ Interview with Mujio Nurkholis, PW NU West Barat, May 14, 2018.

${ }^{42}$ Interview with Dikdik Dahlan Lukman, PWM West Barat, April 14, 2018.

43 Interview with Dikdik Dahlan Lukman, ..., .. April 14, 2018.

44 Interview with Dikdik Dahlan Lukman, ... April 14, 2018.

${ }^{45}$ Interview with lu Rusliana, PWM East Java, April 14, 2018. about harmony, pluralism, and tolerance, but also requires peace, tranquility, and security. "That is one of the characteristics of Islam being progressives well as civilized," he added. ${ }^{46}$

Similarly, the Regional Leadership of Islam Community Unity (PUI), Engkos Kosasih. He said Islamic principles are full of suggestions to be wise and polite to others. For example, silaturrahim (connecting brotherhood), 'iyadah al-maridh (visiting sick people), al-birr bi alyatamawa al-masakin (supporting orphans and the needy), and al-takafulwa at-tadhamun (hand in hand and solidarity). Therefore, PUI condemns the types of disgraceful acts that harm others, such as gibah (gossiping), namimah (turning someone against someone else), al-hasadwa alhiqd (envy and jealousy), anâniy (egoism), and actions lead to radicalism and intolerance. ${ }^{47}$ While Iding Bahruddin, said, despite the name Islam Community Unity which could be translated to accommodate all Islamic sects (radical, moderate, conservative, and the like), but for those who endanger and threaten unity should not be and do not enter this organization. The Islam Community Unity upholds the middle side concept that is often expressed by the founding father of this organization, K.H. Abdul Halim. Iding continued, at the XII PUI Congress in 2015 in Palembang, PUI launched its identity politics with wasathiyat Islam. This then adds to the treasury in the explanation of intisab (the essence) as an idiil (basic) foundation and Ishlahus Samaniyah as the operational foundation of this organization..$^{48}$

Moreover, Raizal Arifin stated that intolerance perpetrator really deserves severe punishment. The demands of the Youth of Islam Community Unity are very strict, namely: there must be legal justice. If intolerant behavior and actions are left without justice, Raizal continued, it is not impossible that a series of racist attitudes and blasphemy of religion will become an endless arena of enmity and humiliation. ${ }^{49}$

\footnotetext{
${ }^{46}$ Interview with Iu Rusliana, ..., April 14, 2018.

47 Interview with Engkos Kosasih, DPW PUI West Java, May 13, 2018.

${ }^{48}$ Interview with Iding Bahruddin, DPW PUI West Java, May 13, 2018.

49 Interview with Raizal Arifin, DPW PUI Jawa Barat, May 13,2018
} 
According to Samsul Falah, religion is not the only source of conflict. The trigger for intolerant behavior is more caused by nonreligious interests..$^{50}$ Another cause is a large number of cases of religious conversion hiding behind social projects, such as the construction of schools and health services carried out by Christian missionaries in remote areas of West Java. ${ }^{1}$ Converting individual religion is an antidialogic act as well as a form of violation of religious harmony. It's hard to separate Islam from dakwah and Christianity from its missionary. Both of them have an interest in attracting followers of other religions to their beliefs which are considered the most correct. This is what inhibits inter-religious dialogue especially Islam and Christian. As a result, interfaith tension reemerged..$^{52}$ Nevertheless, Islam Community Unity strongly condemns all forms of intimidation, intolerance, discrimination, and assault. ${ }^{53}$

According to Karsidi Diningrat, al-Jam'iyatul Washliyah means a bridging organization. It is expected to connect the members with members; the leaders of branches, with subordinates, and with leaders of regions; one organization with another organization; Muslims with their religion; and connect humans with their God. ${ }^{54}$ Based on all that, continued Karsidi, al-Washliyah tried to connect everything that had to be connected as long as it did not conflict with Allah's commands..$^{55}$

In response to several acts of intolerance in freedom of religion and belief in West Java, al-Washliyah has mobilized all the potential summed up in its charitable efforts. This is in accordance with the philosophy of the name alJam'iyatul Washliyah which means connecting. In educational institutions, al-Washliyah has since inculcated the values of peace and harmony and has embraced the understanding that is antiradical and intolerant. Every student of secondary and high-school must learn these subjects. It

so Interview with Samsul Falah, PW Persatuan Islam (Persis) West Java, June 5, 2018.

${ }^{51}$ Interview with Samsul Falah, ..., June 5, 2018.

${ }^{52}$ Interview with Samsul Falah, ..., June 5, 2018.

53 Interview with Samsul Falah, ..., June 5, 2018.

54 Interview with Karsidi Diningrat, Jam'iyah Al-Wasliyah West Java, June 6, 2018.

55 Interview with Karsidi Diningrat. ..., June 6, 2018. discuss its definition which is a guide, vision, and direction of the organization. The students were introduced to the doctrine that "between nations in the world must underlie discussion with ta'aruf (know each other based on brotherhood). The close friend of al-Washliyah is a party that has the same vision and ideology. Nevertheless, alWashliyah still creates a good relationship with the opposing parties. ${ }^{56}$

The concept of Shibghah was also taught including: loving peace, connecting to each other silaturahim, having Islamic mindset, loving and diligently doing worship, trying and struggling because of God (sincere), fond of helping people who are in difficulties, active in building society and nation, carrying out the remembrance for the good and preventing from the bad, having adequate religious knowledge, always appearing in the midst of the people as an example, happy to be patient and to be the mouthpiece of the people, flexible and not extreme. ${ }^{57}$ Love of peace and silaturrahim (hospitality) are icons which confirm that al-Washliyah rejects violence and disputes. ${ }^{58}$

In accordance with the official attitude of the organization, the al-Washliyah scholars also showed their resistance to radical and intolerant notions. One example, according to lja Suntana, is that intolerant behavior is destructive and anarchic. The aim is to create fear and do it without rules with unlimited goals. For this reason, al-Washliyah is more interested in developing moderate wasathiyah, which is able to unite the two camps in a balanced, harmonious manner, without sacrificing truth values. Moderate ideals do not support the understanding of the far right, such as radicals and terrorists, and do not favor the extreme left, such as liberals. 59

\section{Efforts to Maintain Moderate Islam}

Moderate Islam in West Java is formed by a very long historical struggle. His presence began during the ancient kingdom, the government of

\footnotetext{
${ }^{56}$ Interview with Karsidi Diningrat, ..., June 6, 2018.

57 Interview with Karsidi Diningrat, ..., June 6, 2018.

${ }^{58}$ Interview with Karsidi Diningrat, ..., June 6, 2018.

59 Interview with lja Suntana, Jam'iyah Al-Wasliyah West Java, June 6, 2018.
} 
the Netherlands East Indies, the occupation of Dai Nippon, the war of Independence, the Old Order, the New Order, until now. It had a fruitful period where there was full support from the government as well asstrict supervision of the movement by the government. The five mass organizations have long fought for forms of moderate Islam, both through the educational institutions that they founded and their actions in the other social-political-religious realm that they believe in. Therefore, they deserve to be called the five civil society institutions that are necessary for the country's moderation process. In addition, they play an active role in maintaining and strengthening the network of institutions supporting moderate Islam, so that it becomes a pilot project of tolerance, ${ }^{60}$ and outsiders often refer to West Java as a stronghold of moderate Islam. ${ }^{61}$

West Java, although it is known as a stronghold of moderate Islam, was recently reported to have several Muslim militants who have attacked various religious minorities. In terms of suspects, they are usually moved not by people from Sundanese ethnic. While from the object of attack, they are minority sects and denominations with a limited number of adherents. ${ }^{62}$ On the other hand, the West Java constitution has protected religious freedom, but they (Muslim militants) control the streets. The Regional Government is often powerless to stop these violations. As a result, the label appeared, "West Java is the most intolerant province in Indonesia". The label is clearly a matter that contradicts the philosophy of life of Sundanese people who are always siger tengah (the middle side), non-militant, non-extreme, and non-revolutionary. ${ }^{63}$

Between 2015-2017, it is known that tolerance in West Java is in a serious threat.

${ }^{60}$ Novriantoni Kahar, "Islam Indonesia Kini: Moderat Keluar, Ekstrem di Dalam?”, http:Islamlib.com/id/artikel/islamindonesia-kini-moderat-keluar-ekstrim-di-dalam/, accessed. October 23, 2018.

${ }^{61}$ Novriantoni Kahar, "Islam Indonesia Kini ..., accessed. October 23, 2018.

${ }^{62}$ Kaum Muslim militan tengah meningkatkan perhatian mereka terhadap Budha, Kristen, Syi'ah, dan Ahmadyah.

${ }_{63}$ Tjetje H. Padmadinata, "Panggung Karakter Elite Sunda”, In HU Pikiran Rakyat, April 5, 1997, p. 5.
What is worrying is that the government and various Muslim organizations are lack assistance to those affected. The phenomenon of religious and cultural diversity among human beings is a fact that cannot be denied. To deny this is tantamount to not acknowledging the sun in the noon. Human rights and real religion can be linked. Both can support and strengthen each other. However, togetherness can run optimally if religious leaders and government officials have an understanding of interpretations that are different from their beliefs, including beliefs that are very different from those they believe in, and vice versa. At this stage, it is admitted; outsiders often refer to West Java as a stronghold of moderate Islam.

For this reason, it is an urge to announce Islam is a religion that can create better world. It is sâlih fî kulli zamân wa al-makân (proportional to the time and the age). One thing that needs to be immediately voiced is that moderate Islam is the character and distinction of Indonesian Islam, as well as the wealth of Indonesian legacy. This is the essence of maintaining moderate Islam.

\section{Conclusion}

Conceptually, moderate Islam was frequently examined. However, the distinctive value of Indonesia and West Java in particular is in how the application and actualization of moderate Islam has been going on for a long time now and into the future. It is obvious that the principle of moderation is central Islamic teachings. However, in many ways it is still potential, not yet actual in the lives of Muslims. Moderate Islam contains dimensions of breadth, nobility and beauty. This teaching brings peace, order and harmony. Therefore, it is the religious responsibility of Muslims throughout the world to practice it.

The violation of Freedom of Religion / Belief (KKB) in West Java has not yet indicated that it will end soon. There are internal, cross- and inter-religious factors with the government that support and hinder efforts to minimize the case. For this reason, caring for and giving space to the moderate Islam mass organizations are very significant to be used as a reference frame in the pattern of behavior and religious pattern 
of the community. Moderate Islam contains dimensions of breadth, nobility, and beauty. If actually enacted, it will bring peace, order and harmony. The community becomes polite, civilized and organized (an important feature of the ideals of civil society)

\section{References}

Dirjen Pendis Kemenag RI, Rencana Strategis Direktorat Jenderal Pendidikan Islam Tahun 2015-2019, Jakarta: Dirjen Pendis Kemenag RI, 2015

Halili and Bonar Tigor Naipospos, Laporan Kondisi Kebebasan Beragama/Berkeyakinan di Indonesia 2015: Politik Harapan Minim Pembuktian, Jakarta: Pustaka Masyarakat Setara, 2016

Himawan, Furqon Ulya. "Kalahkan Jawa Barat DKI Jakarta Jawara Intoleran", in http:// mediaindonesia.com/-read/detail/179687kalahkan-jawa-barat-dki-jakarta-jawaraintoleran, accessed, August 26, 2018

Kahmad, Dadang "Kajian tentang Pengambilan Keputusan untuk menjadi Pengikut Tarekat Qadiriyah Naqsabandiyah; Studi Kasus di Kecamatan Ujungberung Bandung", Thesis. Universitas Padjadjaran Bandung, 1993

Khalikin, Ahsanul and Fathuri, Toleransi Beragama di Daerah Rawan Konflik, Jakarta: Puslitbang Kehidupan Keagamaan Badan Litbang dan Diklat Kemenag RI, 2016

Komnas HAM, Laporan Tahunan Kebebasan Beragama dan Berkeyakinan 2016, Jakarta: Komnas HAM, 2017

, Laporan Tahunan Kebebasan Beragama dan Berkeyakinan 2016, Jakarta: Komnas HAM, 2016

Kuntowijoyo, Paradigma Islam Interpretasi Untuk Aksi, Bandung: Mizan, 1991

L. Esposito, John et al. Moderat Atau Radikal, Jakarta: Referensi, 2012

Ma'arif, Ahmad Syafi'l, Islam dalam Bingkai Keindonesiaan dan Kemanusiaan; Sebuah Refleksi Sejarah, Bandung: Mizan, 2009

Mellisa, Ayu et al., Mengukur Kebebasan Beragama di Jawa Barat 2014: Catatan dari Indeks Demokrasi Indonesia, Jakarta: PUSAD Paramadina, 2016
Naipospos, Bonar Tigor and Halili, Ringkasan Eksekutif: Laporan Tengah Tahun Kondisi Kebebasan Beragama/Berkeyakinan dan Minoritas Keagamaan di Indonesia 2018, Jakarta: Pustaka Masyarakat Setara, 2018

Novriantoni Kahar, "Islam Indonesia Kini: Moderat Keluar, Ekstrem di Dalam?”, http:Islamlib.com/ id/artikel/islam-indonesia-kini-moderat-keluarekstrim-di-dalam/, accessed, Oktober 23, 2018.

Nurhadi M. Musawir (ed.), Dinamika Pemikiran Islam dan Muhammadiyah: Almanak Muhammadiyah Tahun 1997 M./1417-1418, Yogyakarta: Pustaka Pelajar, 1997

PB Al-Washliyah, Anggaran Dasar Al-Jam'iyatul Washliyah, Medan: PB AI-Washliyah, 2005

PB NU, Anggaran Dasar Nahdlatul Ulama, Jakarta: PB NU, 2010

PB NU, Nahdlatul Ulama Kembali Ke Khittah 1926, Bandung: Risalah, 1984

PB PUI, Badan Hukum, Anggaran Dasar/ART "PUI", Majalengka: PB PUI Majlis Penyiaran, Penerangan dan Dakwah, 1989

PP Muhammadiyah, Anggaran Dasar dan Anggaran Rumah Tangga Muhammadiyah, Jakarta: PP Muhammadiyah, 2005

PP Persis, Qanun Asasi/Qanun Dakhili Persis, Bandung: PP Persis, 1991

Ridwan, Paradigma Politik NU: Relasi Sunni-NU Dalam Pemikiran Politik, Purwokerto: STAIN Purwokerto Press, 2004

Riyadi, H, Koeksistensi Damai dalam Masyarakat Muslim Modernis. Wawasan: Jurnal IImiah Agama dan Sosial Budaya, Vol 1, No.1, 2016. Setara Institute, Report Summary Tolerant City Index 2015, Jakarta: Setara Institute, 2015

Sukawarsini Djelantik et al., Teroris Medan Kekerasan Berlatar Belakang Agama Di Jawa Barat, Bandung: LP2M Universitas Parahyangan, 2013

Syamsuddin, Din et al.,Wasatiyyat Islam Untuk Peradaban Dunia: Konsepsi Dan Implementasi, Bogor: Usulan Indonesia untuk Konsultasi Tingkat Tinggi Ulama dan Cendekiawan Muslim Dunia Tentang Wasatiyyat Islam Bogor, 2018

Syamsudin, Din, "Etika Kerukunan Internal Umat Islam dalam" in Desk KBB Komnas HAM Bekerja sama dengan HRWG https:// 
hakberagama.or.id/penjelasan-prof-dr-dinsyamsuddin-tentang-etika-kerukunan-internalumat-islam/, accessed, October 282018.

The Wahid Institute, Laporan Tahunan Kemerdekaan Beragama/Berkeyakinan (KBB) di Indonesia: "Utang" Warisan Tak Kunjung Terlunasi, Jakarta: The Wahid Insttute, 2015
Tjetje H. Padmadinata, “Panggung Karakter Elite Sunda", in HU Pikiran Rakyat 1997,

Wawan Hernawan, Seabad Persatuan Ummat Islam, Bandung: PUI dan YMSI Cabang Jawa Barat, 2014. 